\title{
Implications of Venture Capital on Companies' M\&A Goodwill Bubbles: Evidence from Chinese Listed Companies
}

\author{
Congcong Wang $\mathbb{D}^{1},{ }^{1}$ Juntao Lan $\mathbb{D},^{1,2}$ and Zhiqiang Zhang $\mathbb{D}^{3}$ \\ ${ }^{1}$ School of Accounting, Zhongnan University of Economics and Law, Wuhan 430073, China \\ ${ }^{2}$ Jining Medical University, Jining 272067, Shandong Province, China \\ ${ }^{3}$ College of Management and Economics, Tianjin University, Tianjin 300072, China \\ Correspondence should be addressed to Juntao Lan; 201701090024@stu.zuel.edu.cn
}

Received 2 October 2021; Revised 3 January 2022; Accepted 13 January 2022; Published 16 February 2022

Academic Editor: Baogui Xin

Copyright (C) 2022 Congcong Wang et al. This is an open access article distributed under the Creative Commons Attribution License, which permits unrestricted use, distribution, and reproduction in any medium, provided the original work is properly cited.

\begin{abstract}
The problem of goodwill bubbles is an important issue concerned by the current capital market. It is of great significance to explore the influencing factors of goodwill bubbles for effectively inhibiting goodwill bubbles and preventing and resolving financial risks. Taking A-share companies listed from 2014 to 2018 in China as samples, this study empirically tests the impact of venture capital institutions on M\&A goodwill bubbles. We find that, compared with nonventure capital shareholding companies, the scale of M\&A excess goodwill of venture capital shareholding companies is lower. That is, venture capital institutions can effectively inhibit M\&A goodwill bubbles. The research on the impact mechanism shows that the inhibition of venture capital institutions on the M\&A goodwill bubbles is mainly realized by reducing information asymmetry and easing agency conflict. Further research shows that, from the perspective of the participation of venture capital institutions, the higher the shareholding of venture capital institutions and the greater the number of venture capital institutions investing in the same company, the more they can inhibit M\&A goodwill bubbles. From the perspective of internal and external governance environment, venture capital institutions are more able to inhibit M\&A goodwill bubbles in enterprises with poor quality of internal control and marketization level.
\end{abstract}

\section{Introduction}

General Secretary Xi Jinping pointed out that preventing and dissolving financial risks, especially preventing the occurrence of systematic financial risks, is the fundamental task of financial work. Since 2014, with the promulgation of "Opinions of the State Council on Further Optimizing the Market Environment of Enterprise Mergers and Reorganizations," the M\&A activities of listed companies in China have ushered in a new round of explosive growth. "Doublehigh" M\&A activities with high valuation and high-performance commitments are more common [1]. "Doublehigh" M\&A activities promote the rapid increase in the scale of listed companies' goodwill assets, and goodwill bubbles accumulated. According to WIND data, by the end of 2018, the amount of goodwill assets of A-share listed companies exceeded CNY 1.3 trillion. Among them, 871 listed companies in 2018 totaled CNY165.86 billion of goodwill impairment, accounting for $12.7 \%$ of the total goodwill amount, which is about 4.5 times of 2017 and 14.5 times of 2016. The short-term depreciation of goodwill assets will not only change the company's performance and trigger stock price crash risk [2] but also have a substantial impact on the capital market as a whole and trigger systemic financial risk [3]. Therefore, it is of great significance to explore the influencing factors of goodwill bubbles for effectively inhibiting goodwill bubbles and preventing and resolving financial risks.

In terms of theoretical research, existing literature research studies on the influencing factors of M\&A goodwill bubbles are mainly carried out from two aspects: internal influencing factors and external influencing factors. Internal influencing factors mainly include earnings management, debt and compensation contracts, CEO 
characteristics, background of audit, committee members, internal control, and corporate social responsibility [4-9]. External factors mainly include the macroeconomic environment and external supervisory institutions such as auditors and institutional investors [10-12]. Different from the perspective of previous studies, we will examine the impact of venture capital institutions on M\&A goodwill bubbles from the perspective of another important external investor in the paper. Different from general institutional investors, venture capital institutions not only provide the necessary financial resources for the development of enterprises but also actively participate in the investment management of enterprises and provide various valueadded services for enterprises. The study have found that many venture capital institutions did not exit the listed companies within 3-5 years after the successful listing of the companies due to the restriction of the equity lockup period or the profit from continuing to hold the shares of the listed companies [13]. During the sample period of this paper, the exit rate of venture capital institutions is relatively low. Statistics show that the exit rate of venture capital institutions accounts for about $27.7 \%$ three years after the company is listed, and nearly $40 \%$ of venture capital institutions continue to hold the shares of the listed company five years after the company is listed. Then, in the stage from IPO to exit of venture capital institutions, can venture capital institutions participate in M\&A of listed companies effectively inhibit the M\&A goodwill bubbles? What is the mechanism of action between them? Are there any differences between venture capital institutions with different backgrounds? Does the difference of internal and external environment affect the inhibition of venture capital institutions on the M\&A goodwill bubbles?

Based on these problems, taking A-share companies listed from 2014 to 2018 in China as samples, this study empirically tests the impact of venture capital institutions on M\&A goodwill bubbles. It is found that the scale of excess goodwill in M\&A of enterprises with venture capital institutions is lower than that of enterprises with no venture capital institutions. That is, venture capital institutions can effectively inhibit M\&A goodwill bubbles. After using Heckman two-stage regression, propensity score matching (PSM), double difference method (DID), adding control variables, and replacing the interpreted variables for robustness test, the above conclusions are still valid. The research on the impact mechanism shows that the inhibition of venture capital institutions on the M\&A goodwill bubbles is mainly realized by reducing information asymmetry and easing agency conflicts between managers and shareholders and between major shareholders and minority shareholders. Further research shows that, from the perspective of the participation of venture capital institutions, the higher the shareholding of venture capital institutions and the greater the number of venture capital institutions investing in the same company, the more they can inhibit M\&A goodwill bubbles. From the perspective of internal and external governance environment, venture capital institutions are more able to inhibit M\&A goodwill bubbles in enterprises with poor quality of internal control and marketization level.
The marginal contributions of this paper are as follows: (1) it expands the related research in the field of M\&A goodwill bubbles to take venture capital institutions as the influencing factors of M\&A goodwill bubbles for the first time. (2) It enriches the research literature on the impact of venture capital institutions on the economic consequences of M\&A. The existing literature on the impact of venture capital institutions on the economic consequences of M\&A mainly focuses on the impact of venture capital institutions on the direct economic consequences of M\&A performance [14], but no one has paid attention to the impact of venture capital on the implicit economic consequences of goodwill bubble of M\&A. It is a new attempt to expand the research of venture capital institutions on the economic consequences of M\&A to the field of M\&A goodwill bubbles. (3) This study shows that venture capital institutions can effectively inhibit the M\&A goodwill bubbles, which can provide a reference for companies to improve the decision-making mechanism of M\&A and for regulatory authorities to optimize regulatory policies.

The structure of this study is as follows: we give the literature review and research hypothesis in the following. Section 2 shows the research design, Section 3 gives the empirical analysis, and Section 4 carries on the robustness test. The impact mechanism is researched in Section 5, and some further analyses are shown in Section 6. Section 7 concludes the whole study.

1.1. Literature Review. M\&A goodwill is generated by premium payments. It should be divided into two parts: the reasonable part and the overvalued part. Only reasonable part is the embodiment of expected future excess profitability and should be recognized as goodwill [15]. However, it is a pity that the goodwill of most enterprises cannot objectively reflect the true value of the underlying assets, and overvaluation is a common problem [16]. Studies have found that the high goodwill paid by enterprises not only reduces the future performance of themselves [17] but also inhibits the level of technological innovation of enterprises [18]. When the goodwill of an enterprise is subsequently impaired, investors will give a negative evaluation to the enterprise. This will lead to the decline of the enterprise's stock price and even cause a crash in stock prices [2, 19]. Therefore, auditors often take goodwill as a risk signal when pricing. The larger the scale of goodwill, the higher the audit fees, especially when goodwill impairment occurs in these companies, the audit fees increase more [20]. So, how can enterprise inhibit the goodwill bubbles? Scholars have found that a good internal and external supervision governance mechanism can effectively inhibit M\&A goodwill bubbles. In terms of internal oversight, Abughazaleh et al. found that effective corporate governance could inhibit the M\&A goodwill bubbles [21]. Zhang Xinmin et al. found that, by strengthening internal control and fulfilling social responsibilities, the company could effectively reduce the proportion of M\&A goodwill and goodwill impairment, thereby effectively inhibiting the M\&A goodwill bubbles [8]. Xu Gang found that corporate social responsibility performance 
and information disclosure as an effective internal governance mechanism could improve the fairness of goodwill valuation, thereby effectively inhibiting the M\&A goodwill bubbles [9]. In terms of external supervision, $\mathrm{Li} \mathrm{Lu}$ and Yao Haixin found that shared audit could significantly reduce the scale of new goodwill of the acquirer, the probability of impairment of goodwill in subsequent M\&A, and the accrual proportion of goodwill impairment [11]. Glaum et al. found that public supervision and external supervision of auditors and institutional investors could help to improve the timeliness of enterprises' recognition of goodwill impairment [12].

With the rise of innovation and entrepreneurship, Chinese enterprises are increasingly appreciated by venture capital institutions [22]. The value-added effect of venture capital institutions on enterprises has been widely concerned and recognized by scholars. It is found that the certification and supervision function of venture capital institutions can reduce the information risk and improve the internal governance mechanism of enterprises, so as to have a positive impact on corporate governance, corporate strategy, innovation activities, operation activities, investment and financing activities, audit pricing, and so on. In recent years, with the deepening of research, scholars began to pay attention to the impact of venture capital institutions on corporate M\&A activities. Chinese scholars Li Yao and Song $\mathrm{He}$ first studied the impact of venture capital on listed companies in the field of M\&A. They found that the holding of venture capital institutions could significantly improve the short-term and long-term performance of companies after the announcement of M\&A [16]. Subsequently, Li Shanmin et al. explored the impact of remote venture capital institutions on enterprise's remote performance of M\&A, and they found that when the host company had remote venture capital institutions shareholders from the location of the target company, the enterprise's remote M\&A performance was better [23]. Dong Jing et al. found that the richer the regional investment experience of venture capital institutions was, the more inclined the invested enterprises were to carry out long-distance M\&A [24]. Nguyen and $\mathrm{Vu}$ found that venture capital syndication could create longterm value for startups and their acquirers [25].

To sum up, we find that some scholars began to explore the impact of venture capital institutions on the economic consequences of M\&A. However, the focus of their attention is mainly on the impact of venture capital institutions on the corporate M\&A performance. No one has paid attention to the impact of venture capital institutions on the corporate M\&A goodwill bubbles. M\&A goodwill, as a product of premium M\&A, has become a reservoir of M\&A risks due to its large space for professional judgment [16], which has also resulted in a series of adverse economic consequences. Therefore, it is particularly important to explore the influencing factors of M\&A goodwill. However, the existing literature has not paid attention to the influence of venture capital institutions as a special external investor on the goodwill of M\&A, which leaves room for our research.
1.2. Research Hypothesis. The valuation deviation of the target assets and the agency problems are the main reasons for the overvaluation of goodwill [15]. In view of the agency problems because the goodwill criteria give the management more discretion, it is easy to induce the opportunistic behavior of the management [26]. They may overestimate the goodwill to achieve the purpose of raising the stock price in the short term, and then delay or underreport the impairment to boost performance [27]. In addition, in recent years, a large number of mergers and acquisitions have occurred in the capital market. The market prosperity has promoted the optimism and confidence of the management, which will further promote the goodwill bubbles [28]. Due to the relatively concentrated equity of listed companies in China, the phenomenon of monopoly is widespread. In the process of M\&A, major shareholders may have the motivation to deliver benefits. By means of related merger and acquisition, they make use of the asset evaluation results to carry out high-premium M\&A, which leads to high goodwill assets in listed companies. As an active institutional investor, the role of certification and supervision of venture capital institutions can not only help the invested enterprises accurately evaluate the target asset value but also effectively inhibit the opportunism motivation of management and the benefit encroachment motivation of major shareholders and effectively inhibit the M\&A goodwill bubbles. The specific reasons are as follows.

First of all, venture capital institutions have a certification function which can transmit reliable information about the true value and quality of enterprises to the outside, thus effectively reducing the degree of information asymmetry between the acquirer and the target party as well as between the acquirer and various market intermediaries [29], which helps to alleviate the problem of overvalued goodwill of the invested enterprises. On the one hand, in the process of M\&A, the target party needs to know the financial strength and real intention of the acquirer out of consideration of its own interests, and the venture capital institutions among the acquirer shareholders can send the signal that the acquirer is of good quality to the target party. This can reduce the degree of information asymmetry between the acquirer and the target party, thus alleviating the conflict and suspicion of the target party and reducing the acquisition cost [14]. On the other hand, the certification role of venture capital institutions on the enterprise value of the acquirer can reduce the degree of information asymmetry between the acquirer and various market intermediaries. This can help the acquirer establish a good cooperative relationship with various market intermediaries and form a wide social relationship network [30]. The establishment of a social relationship networks can not only help the acquirer scan, search, and select high-quality M\&A objects in a wider range. After locking the M\&A objects, it can also help the acquirer make a more comprehensive and detailed analysis and judgment on the financial and nonfinancial information such as assets, profits, cash flow, and strategy of the target party, and accurately evaluate the asset value of the target 
party, to alleviate the problem of overestimation of M\&A goodwill caused by valuation deviation.

Secondly, venture capital institutions have a supervision function which helps to alleviate the problem of overvaluation of goodwill caused by agency problems. As capital providers, the ultimate goal of venture capital investments are to obtain the capital income and usually do not seek the control right of the invested enterprise, which determines that there may be agency conflicts between the venture capital institutions and the major shareholders of the invested enterprise. In addition, as shareholders, venture capital institutions are the owners of enterprises, and there may be agency conflicts between them and management. Therefore, in order to exit smoothly and obtain capital exit income, venture capital institutions have motivation and pressure to alleviate these two types of agency conflicts. It is found that, after venture capital institutions decide to invest in enterprises, on the one hand, they will continuously supervise the invested enterprises by assisting the invested enterprises in recruiting managers, appointing or dismissing CEOs, implementing phased financing and carrying out convertible bonds $[31,32]$. On the other hand, they often choose to enter the board of directors of the invested enterprise, directly participate in the business decision-making of the enterprise, help the invested enterprise select professionals with financial or financial knowledge background as external directors, and improve the scale and independence of the board of directors of the invested enterprise $[33,34]$. These measures help to reduce agency conflicts caused by major shareholders' encroachment of interests through M\&A and management's opportunistic motives, so as to alleviate the overvaluation of M\&A goodwill. Based on the above analysis, we propose the following hypothesis.

Hypothesis H1: compared with nonventure capital shareholding companies, the scale of M\&A excess goodwill of venture capital shareholding companies is lower.

\section{Research Design}

2.1. Sample Selection and Data Source. This paper establishes an initial sample based on A-share companies listed from 2014 to 2018 and then filters them according to the following criteria: (1) removing listed companies in the financial industry. (2) Remove listed companies in ST. (3) Exclude listed companies with missing data. (4) To eliminate the possible effects of extreme values on the results, all continuous variables are tailed by $1 \%$ from top to bottom. After the above screening, 2162 companies' annual observation samples are obtained. The venture capital data required for the research comes from the CVSOURCE database, the goodwill data comes from the Wind database, the institutional environment data comes from the marketization index of the "China's Marketization Index Report by Provinces (2018)" compiled by Wang Xiaolu, the internal control data comes from the internal control evaluation index of listed companies in the Dibo database and all other data needed for the research comes from the Guotaian database.
When judging whether a company has a venture capital institution, we draw on the research of Dong Jing et al. and Hu Liufen and Zhou ZeJiang [35, 36], and we identify it according to the following criteria: (1) the nature of the venture capital institution is PE-Growth or VC-Serise (investment rounds include $\mathrm{A}, \mathrm{B}, \mathrm{C}, \mathrm{D}$, and $\mathrm{E}$ ), and the investment point is before the IPO of enterprises. (2) Obtain the list of ten shareholders of a listed company from the Guotaian database. If at least one of the top ten shareholders is a venture capital institution (venture capital fund), then confirm that the listed company has the background of holding stock of a venture capital institution.

2.2. Model Design and Variable Definition. We mainly focus on the influence of venture capital institutions on the M\&A goodwill bubbles in this paper and consider that other variables may also have an impact on the M\&A goodwill bubbles. Therefore, referring to the research of Zhang Xinmin et al. and Xu Gang [8,9], we set up the following multiple linear regression equation:

GWover $_{i, \mathrm{t}}=\alpha+\beta_{0} V C_{\mathrm{i}, \mathrm{t}}+\beta_{1}$ Control $_{\mathrm{i}, \mathrm{t}}+$ Year $_{\mathrm{i}, \mathrm{t}}+\operatorname{Ind}_{\mathrm{i}, \mathrm{t}}+\varepsilon_{\mathrm{i}, \mathrm{t}}$.

In (1), the interpreted variable is GWover $_{i, t}$, which indicates the excess goodwill of enterprise $i$ in year $t$, which is used to measure the M\&A bubbles. Following Ramanna, Zhang Xinmin et al. and Xu Gang $[8,9,26]$ to measure excess goodwill, we divide the difference between the book value of goodwill of enterprise $i$ in year $t$ minus the average book value of goodwill of the industry in which the enterprise $i$ works by the total assets of enterprise $i$. The explanatory variable is $\mathrm{VC}$, which is a virtual variable, indicating whether the listed company $i$ is held by a venture capital institution in year $t$. If the listed company $i$ is held by a venture capital institution in year $t$, the value of $\mathrm{VC}$ is 1 ; otherwise, it is 0 . If the coefficient $\beta_{0}$ of explanatory variable $\mathrm{VC}_{i, t}$ is significantly negative, it indicates that venture capital institutions can significantly inhibit the M\&A goodwill bubbles. Control ${ }_{i, t}$ is a series of control variables. Referring to the model of Ramanna, Zhang Xinmin et al. and Xu Gang $[8,9,26]$, we control the following variables: asset size $\left(\right.$ LnSize $\left._{i, t}\right)$, property rights $\left(\mathrm{SOE}_{i, t}\right)$, market-to-account ratio $\left(\mathrm{MB}_{i, t}\right)$, total return on assets $\left(\mathrm{ROA}_{i, t}\right)$, asset liability ratio $\left(\operatorname{LEV}_{i, t}\right)$, auditor selection $\left(\operatorname{Big} 4_{i, t}\right)$, equity concentration $\left(\operatorname{Top}_{i, t}\right)$, net profit growth rate (Growth $\left.{ }_{i, t}\right)$, and operating capacity (Turnover $r_{i, t}$ ). Besides, we estimate equation (1) including year and industry fixed effects and cluster standard errors by enterprise. Detailed variable descriptions and definitions are given in Table 1.

\section{Empirical Analysis}

3.1. Descriptive Statistics. Table 2 lists the descriptive statistical results of each variable. Among them, the median value of GWover is -0.14 , and the maximum value is 0.27 , indicating that some enterprises have confirmed large excess goodwill. The average $\mathrm{VC}$ value is 0.47 , indicating that the venture capital institutions hold about $47 \%$ of the total sale, 
TABle 1: Variable description and definition.

\begin{tabular}{|c|c|c|c|}
\hline Variable type & Variable name & $\begin{array}{l}\text { Variable } \\
\text { symbols }\end{array}$ & Variable definition \\
\hline $\begin{array}{l}\text { Interpreted } \\
\text { variable }\end{array}$ & Excess goodwill & GWover & $\begin{array}{l}\text { (The book value of goodwill of enterprise-the average book value of } \\
\text { goodwill of the industry)/total assets }\end{array}$ \\
\hline \multirow[t]{6}{*}{$\begin{array}{l}\text { Explanatory } \\
\text { variable }\end{array}$} & Risk investment & $\mathrm{VC}$ & $\begin{array}{c}\text { A virtual variable that equals } 1 \text { for enterprise held by venture capital } \\
\text { institutions, and } 0 \text { otherwise }\end{array}$ \\
\hline & Company size & LnSize & Log of final total assets \\
\hline & $\begin{array}{l}\text { Nature of the property } \\
\text { right }\end{array}$ & SOE & A virtual variable that equals 1 for state-owned enterprise, and 0 otherwise \\
\hline & Market-account ratio & MB & Ratio of market value to book value \\
\hline & Return on total assets & $\mathrm{ROA}$ & Net profit $\times 2 /$ (initial total assets + final total assets) \\
\hline & Assets and liabilities & LEV & Final total assets/final total liabilities \\
\hline \multirow[t]{6}{*}{ Control variable } & Auditor selection & Big4 & $\begin{array}{l}\text { A virtual variable that equals } 1 \text { for enterprises that are audited by a big } 4 \text {, and } \\
0 \text { otherwise }\end{array}$ \\
\hline & Equity concentration & Top1 & Shareholding ratio of the largest shareholder \\
\hline & Net profit growth rate & Growth & (Ending net profit-beginning net profit)/ beginning net profit \\
\hline & Operating capacity & Turnover & Total operating income $\times 2 /($ initial total assets + final total assets $)$ \\
\hline & Year & Year & Year fixed effects \\
\hline & Industry & Ind & $\begin{array}{l}\text { Industry fixed effects divided according to the } 2012 \text { edition of the industry } \\
\text { classification of the CSRC }\end{array}$ \\
\hline
\end{tabular}

TABLE 2: Variable descriptive statistics.

\begin{tabular}{lcccccc}
\hline Variable & Size & Average & SD & Median & Minimum & Maximum \\
\hline GWover & 2162 & -0.18 & 0.21 & -0.14 & -1.01 & 0.27 \\
VC & 2162 & 0.47 & 0.50 & 0.00 & 21.29 & 1.00 \\
LnSize & 2162 & 21.42 & 0.90 & 0.00 & 0.99 & 24.71 \\
SOE & 2162 & 0.09 & 0.28 & 1.72 & 0.00 & 1.01 \\
MB & 2162 & 1.95 & 0.84 & 0.06 & -0.12 & 0.06 \\
ROA & 2162 & 0.07 & 0.17 & 0.32 & 0.00 & 0.23 \\
LEV & 2162 & 0.34 & 0.17 & 36.25 & 0.19 & 1.00 \\
Big4 & 2162 & 0.03 & 14.40 & 0.10 & -6.57 & 0.14 \\
Top1 & 2162 & 37.58 & 0.98 & 0.57 & 2.78 \\
Growth & 2162 & 0.02 & 0.36 & & 2.33 \\
Turnover & 2162 & 0.66 & & & \\
\hline
\end{tabular}

which means that there are still a considerable number of venture capital institutions not quitting after the company is listed. This provides an opportunity for us to study the impact of venture capital institutions on excess goodwill after the company is listed. The average value of Top1 is $37.5 \%$, which indicates that the phenomenon of dominance of listed companies in China is obvious, major shareholders may encroach on the interests of minority shareholders in order to satisfy their personal interests. Meanwhile, the maximum value of Top 1 is $76.22 \%$, the minimum value is $9.19 \%$, and the standard deviation is 14.4 . This shows that the proportion of the first largest shareholder of listed companies in China is quite different and has a large fluctuation. The standard deviation of all variables except Top1 is less than 1, and the descriptive statistics of the major variables are not abnormal.

3.2. Correlation Analysis. Table 3 shows the correlation analysis results of each variable. The lower triangle lists the Pearson correlation coefficient, and the upper triangle lists the Spearman correlation coefficient. The results show that GWover is significantly negatively correlated with VC, indicating that compared with nonventure capital shareholding companies, the scale of M\&A excess goodwill of venture capital shareholding companies is lower, which preliminarily verifies hypothesis $\mathrm{H} 1$. In addition, the maximum correlation coefficient between explanatory variables is 0.57 and the maximum VIF is 2.33 , which is far less than 10 , indicating that there is no multi-colinearity problem among these variables, and this has reached a basis for the next regression analysis.

3.3. Regression Analysis. Table 4 lists the empirical regression results of hypothesis H1. Among them, column (1) lists the single regression results of venture capital institutions and M\&A excess goodwill, and column (2) lists the multiple linear regression results of venture capital institutions and M\&A excess goodwill after the addition of control variables. In Table 4 , the coefficients of VC are all negative, and it passes the significance test at the level of $5 \%$, which shows that the scale of M\&A excess goodwill of enterprises with venture capital institutions is lower than that of enterprises with no venture capital institutions, assuming $\mathrm{H} 1$ is verified. 


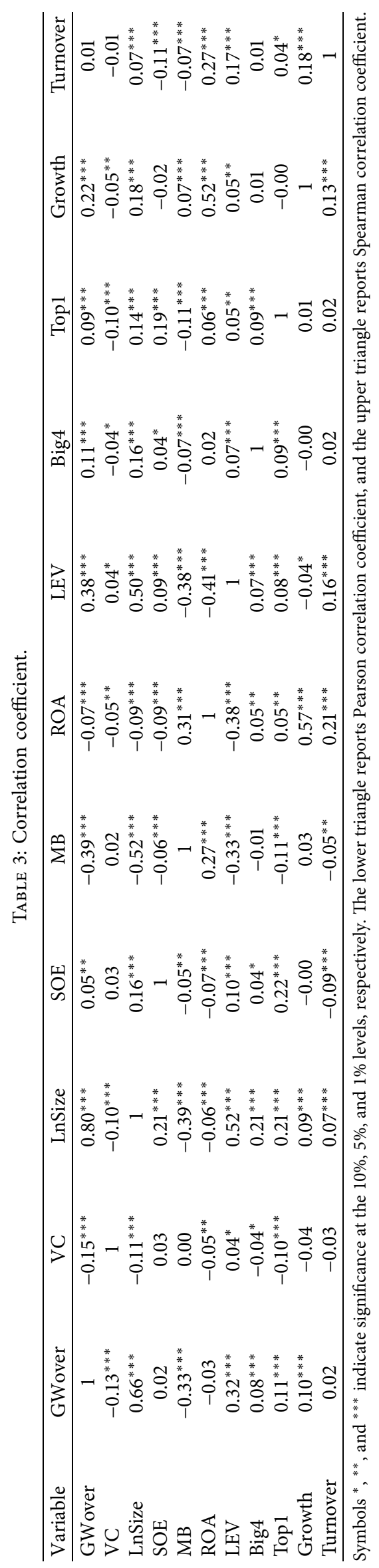


TABLE 4: Regression results.

\begin{tabular}{|c|c|c|}
\hline Variable & $\begin{array}{c}\text { (1) } \\
\text { GWover }\end{array}$ & $\begin{array}{c}(2) \\
\text { GWover }\end{array}$ \\
\hline VC & $\begin{array}{c}-0.038^{* * *} \\
(-4.37)\end{array}$ & $\begin{array}{c}-0.015^{* *} \\
(-2.51)\end{array}$ \\
\hline LnSize & & $\begin{array}{c}0.171^{* * *} \\
(29.23)\end{array}$ \\
\hline SOE & & $\begin{array}{c}-0.047^{* * *} \\
(-4.33)\end{array}$ \\
\hline MB & & $\begin{array}{c}-0.021^{* * *} \\
(-4.38)\end{array}$ \\
\hline ROA & & $\begin{array}{c}-0.299^{* * *} \\
(-3.37)\end{array}$ \\
\hline LEV & & $\begin{array}{l}-0.035 \\
(-1.46)\end{array}$ \\
\hline Big4 & & $\begin{array}{l}-0.035 \\
(-1.59)\end{array}$ \\
\hline Top1 & & $\begin{array}{c}-0.001^{* * *} \\
(-4.11)\end{array}$ \\
\hline Growth & & $\begin{array}{c}0.016^{* * *} \\
(3.43)\end{array}$ \\
\hline Turnover & & $\begin{array}{c}-0.036^{* * *} \\
(-3.95)\end{array}$ \\
\hline Intercept & $\begin{array}{l}0.110 \\
(5.80)\end{array}$ & $\begin{array}{c}-3.636^{* * *} \\
(-27.54)\end{array}$ \\
\hline Year & Controlled & Controlled \\
\hline Ind & Controlled & Controlled \\
\hline $\mathrm{N}$ & 2162 & 2162 \\
\hline $\mathrm{ADJ} R^{2}$ & 0.19 & 0.63 \\
\hline
\end{tabular}

Symbols ${ }^{*},{ }^{* *}$, and ${ }^{* * *}$ indicate significance at the $10 \%, 5 \%$, and $1 \%$ levels, respectively. The value output in parentheses is the $t$ value.

\section{Robustness Test}

4.1. Heckman's Two-Stage Return. There may be endogenous problems in the relationship between venture capital institutions and M\&A goodwill. Those enterprises selected by venture capital institutions may acquire excess goodwill is lower, which is not caused by venture capital institutions. It makes the samples have selective errors. So, we use Heckman two-stage regression to deal with the possible adverse effects of endogenous problems on empirical results. In the first stage, we select LnSize, SOE, LEV, Growth, and Turnover, whether it belongs to the high-tech industry (HT), and whether the registered place of the company belongs to the developed area of venture capital (VC_Develop). China's venture capital is mostly distributed in Beijing, Shanghai, Guangdong, Jiangsu, and Zhejiang. If the listed company is registered in the above five places, the value of VC_Develop will be 1, otherwise 0 . As a participating equation, the inverse Mill ratio (lambda) is obtained and then added to equation (1) to regress. The results are shown in Table 5.

In Table 5, the first-stage regression results of Heckman are listed in column (1), and the corresponding second stage regression results are listed in column (2). After regression, the coefficient of $\mathrm{VC}$ is -0.016 and passes the significance test at the $1 \%$ level, indicating that compared with companies with no venture investment institutions, the scale of M\&A excess goodwill of enterprises with venture investment institutions is lower. Hypothesis $\mathrm{H} 1$ has been verified again.

4.2. Propensity Score Matching (PSM) Analysis. In addition to Heckman two-stage regression, we also used PSM analysis to alleviate endogenous problems. First, we use the venture capital institution (VC) as the explanatory variable, add the control variable in equation (1), use logistic regression to estimate the sample's propensity score, and then use the propensity score to match radius. The covariate balance testing results after matching are shown in Table 6. In Table 6 , we find that, before radius matching, there are significant differences in LnSize, ROA, LEV, Big4, and Top1 between enterprises with venture capital institutions(treated group) and enterprises with no venture capital institutions (control group). After match radius, the bias of these indicators decreased significantly between the two groups of samples, and the $P$ values are much higher than 0.1 . This indicates that there are no significant differences between the variables of the two samples after matching. Then, we conduct a regression analysis for the matched samples again, and the results are shown in Table 7 . In Table 7, the coefficient of VC is -0.015 and passes the significance test at the level of $1 \%$, which shows that compared with enterprises with no venture capital institutions, enterprises with venture capital institutions have a lower scale of excess goodwill. Hypothesis $\mathrm{H} 1$ has been verified again. 
TABLE 5: Heckman two-stage regression.

\begin{tabular}{|c|c|c|}
\hline Variable & $\begin{array}{l}(1) \\
\text { VC }\end{array}$ & $\begin{array}{c}(2) \\
\text { GWover }\end{array}$ \\
\hline $\mathrm{VC}$ & & $\begin{array}{c}-0.016^{* * *} \\
(-2.90)\end{array}$ \\
\hline Lambda & & $\begin{array}{c}-0.897^{* * *} \\
(-6.98)\end{array}$ \\
\hline LnSize & $\begin{array}{c}-0.289^{* * *} \\
(-6.96)\end{array}$ & $\begin{array}{c}0.346^{* * *} \\
(13.50)\end{array}$ \\
\hline SOE & $\begin{array}{c}0.190^{*} \\
(1.68)\end{array}$ & $\begin{array}{c}-0.161^{* * *} \\
(-8.14)\end{array}$ \\
\hline MB & & $\begin{array}{c}-0.023^{* * *} \\
(-4.82)\end{array}$ \\
\hline ROA & & $\begin{array}{c}-0.353^{* * *} \\
(-4.04)\end{array}$ \\
\hline LEV & $\begin{array}{c}1.167^{* * *} \\
(5.63)\end{array}$ & $\begin{array}{c}-0.729^{* * *} \\
(-7.01)\end{array}$ \\
\hline Big4 & & $\begin{array}{l}-0.027 \\
(-1.34)\end{array}$ \\
\hline Top1 & & $\begin{array}{c}-0.001^{* * *} \\
(-4.40)\end{array}$ \\
\hline Growth & $\begin{array}{l}-0.017 \\
(-0.57)\end{array}$ & $\begin{array}{c}0.027^{* * *} \\
(5.57)\end{array}$ \\
\hline Turnover & $\begin{array}{l}-0.139 \\
(-1.56)\end{array}$ & $\begin{array}{c}0.059^{* * *} \\
(3.72)\end{array}$ \\
\hline $\mathrm{HT}$ & $\begin{array}{l}0.069 \\
(0.90)\end{array}$ & \\
\hline VC_develop & $\begin{array}{l}-0.021 \\
(-0.33)\end{array}$ & \\
\hline Intercept & $\begin{array}{c}6.603^{* * *} \\
(6.78)\end{array}$ & $\begin{array}{c}-6.819^{* * *} \\
(-14.36)\end{array}$ \\
\hline Year & Controlled & Controlled \\
\hline Ind & Controlled & Controlled \\
\hline $\mathrm{N}$ & 2100 & 2100 \\
\hline Pseudo $R^{2} / \mathrm{ADJ} R^{2}$ & 0.05 & 0.65 \\
\hline
\end{tabular}

Symbols ${ }^{*},{ }^{* *}$, and ${ }^{* * *}$ indicate significance at the $10 \%, 5 \%$, and $1 \%$ levels, respectively. The value output in parentheses is the $t$ value or $z$ value.

TABLE 6: Covariate balance testing results.

\begin{tabular}{|c|c|c|c|c|c|c|c|}
\hline \multirow{2}{*}{ Variable } & \multirow{2}{*}{$\begin{array}{c}\text { Unmatched } \\
\text { Matched }\end{array}$} & \multicolumn{2}{|c|}{ Mean } & \multirow{2}{*}{$\begin{array}{l}\text { Bias } \\
(\%)\end{array}$} & \multirow{2}{*}{$\begin{array}{c}\text { \% reduct } \\
\text { |bias } \mid\end{array}$} & \multicolumn{2}{|c|}{$t$ test } \\
\hline & & Treated & Control & & & $t$ & $p>t$ \\
\hline \multirow{2}{*}{ LnSize } & $\mathrm{U}$ & 21.320 & 21.511 & -21.4 & & -4.96 & 0.019 \\
\hline & M & 21.322 & 21.323 & -0.1 & 99.5 & -0.03 & 0.979 \\
\hline \multirow{2}{*}{ SOE } & $\mathrm{U}$ & 0.095 & 0.078 & 6.2 & & 1.45 & 0.148 \\
\hline & M & 0.092 & 0.088 & 1.3 & 79.8 & 0.28 & 0.781 \\
\hline \multirow{2}{*}{ MB } & $\mathrm{U}$ & 1.959 & 1.951 & 1.0 & & 0.23 & 0.819 \\
\hline & $M$ & 1.958 & 1.957 & 0.2 & 83.0 & 0.04 & 0.969 \\
\hline \multirow{2}{*}{$\mathrm{ROA}$} & $\mathrm{U}$ & 0.067 & 0.071 & -9.3 & & -2.16 & 0.031 \\
\hline & M & 0.067 & 0.068 & -2.3 & 75.1 & -0.52 & 0.602 \\
\hline \multirow{2}{*}{ LEV } & $\mathrm{U}$ & 0.345 & 0.331 & 8.2 & & 1.90 & 0.057 \\
\hline & M & 0.344 & 0.340 & 2.4 & 71.0 & 0.54 & 0.592 \\
\hline \multirow{2}{*}{ Big4 } & $\mathrm{U}$ & 0.022 & 0.0341 & -7.6 & & -1.75 & 0.080 \\
\hline & M & 0.022 & 0.019 & 1.6 & 78.9 & 0.42 & 0.676 \\
\hline \multirow{2}{*}{ Top1 } & $\mathrm{U}$ & 36.084 & 38.915 & -19.8 & & -4.58 & 0.000 \\
\hline & $M$ & 36.119 & 36.270 & -1.1 & 94.7 & -0.24 & 0.807 \\
\hline \multirow{2}{*}{ Growth } & $\mathrm{U}$ & -0.019 & 0.050 & -7.0 & & -1.63 & 0.103 \\
\hline & M & -0.020 & 0.000 & -2.1 & 70.3 & -0.45 & 0.652 \\
\hline \multirow{2}{*}{ Turnover } & $\mathrm{U}$ & 0.650 & 0.672 & -6.2 & & -1.44 & 0.149 \\
\hline & M & 0.650 & 0.651 & -0.3 & 95.8 & -0.06 & 0.951 \\
\hline
\end{tabular}


TABLE 7: PSM regression results.

\begin{tabular}{lc}
\hline Variable & GWover_asset \\
\hline VC & $-0.015^{* * *}$ \\
& $(-2.60)$ \\
LnSize & $0.177^{* * *}$ \\
& $(29.49)$ \\
SOE & $-0.048^{* * *}$ \\
& $(-4.39)$ \\
MB & $-0.019^{* * *}$ \\
& $(-3.90)$ \\
ROA & $-0.320^{* * *}$ \\
& $(-3.62)$ \\
LEV & $-0.046^{*}$ \\
& $(-1.89)$ \\
Big4 & -0.022 \\
& $(-0.98)$ \\
Top1 & $-0.001^{* * *}$ \\
& $(-3.51)$ \\
Growth & $0.017^{* * *}$ \\
Turnover & $(3.57)$ \\
Intercept & $-0.037^{* * *}$ \\
Year & $(-4.01)$ \\
Ind & $-3.750^{* * *}$ \\
ADJ $R^{2}$ & $(-27.94)$ \\
\hline Symbols & Controlled \\
& Controlled \\
& 2145 \\
& 0.64 \\
\hline
\end{tabular}

Symbols ${ }^{*},{ }^{* *}$, and ${ }^{* * *}$ indicate significance at the $10 \%, 5 \%$, and $1 \%$ levels, respectively. The value output in parentheses is the $t$ value.

4.3. Difference-in-Difference (DID). In addition to Heckman two-stage regression and PSM analysis, we also use the difference-in-difference (DID) to alleviate the possible endogenous problems. According to the shareholding of venture capital institutions, the sample companies can be divided into the following three groups: (1) the sample companies always held by venture capital institutions; (2) the sample companies never held by venture capital institutions; (3) the sample companies that the venture capital institutions enter first and then exit. Based on the research of slaughter [37], we select the sample companies always held by venture capital institutions as the control group sample, and the sample companies that the venture capital institutions enter first and then exit as the treated group. Because the sample companies that the venture capital institutions enter first and then exit are multitemporal, following the research of Bertrand and mullainathan (2003) [38], we construct the following DID equation:

$$
\begin{aligned}
\text { GWover }_{\mathrm{i}, \mathrm{t}}= & \alpha+\beta_{0} \text { Change }_{\mathrm{i}, \mathrm{t}}+\beta_{1} \text { Control }_{\mathrm{i}, \mathrm{t}} \\
& + \text { Year }_{\mathrm{i}, \mathrm{t}}+\operatorname{Ind}_{\mathrm{i}, \mathrm{t}}+\varepsilon_{\mathrm{i}, \mathrm{t}} .
\end{aligned}
$$

In equation (2), Change $i_{i, t}$ is a dummy variable, which is used to measure the difference of excess goodwill before and after the withdrawal of venture capital institutions. Specifically, when enterprise $i$ changes from an enterprise with venture capital institutions to an enterprise with no venture capital institutions in $t$ year, the value is 1 ; otherwise, it is 0 .
The regression results are shown in Table 8 . In Table 8, the coefficient of Change ${ }_{i, t}$ is 0.039 and passes the significance test at the level of $1 \%$, which shows that, after the venture capital institutions exit from companies, the scale of the excess goodwill increases gradually, and the goodwill bubbles increases. From the opposite side, it shows that venture capital holding can inhibit the M\&A goodwill bubbles. Hypothesis $\mathrm{H} 1$ has been verified again.

4.4. Missing Variable Problem. In addition to the control variables listed above, in order to prevent the impact of missing variables on the regression results, referring to relevant studies $[8,24]$, we added four control variables in equation (1): the proportion of independent directors (indpr), dual, market concentration (HHI), and institutional environment (market). Among them, indpr is defined as the proportion of the number of independent directors in the number of directors; dual is a dummy variable. When the chairman and general manager are held by one person, the value is 1 , otherwise it is 0 ; $\mathrm{HHI}$ is measured by Herfindal index, specifically the proportion of the company's main business income in its industry market share. Market adopts the marketization index in China's Provincial Marketization Index Report (2018) compiled by Wang Xiaolu. As the data listed in the report only come to 2016, we use the trend analysis method (three-year rolling period) to calculate the marketization index from 2017 to 2018. The results are shown in Table 9. In Table 9, the coefficient of VC is -0.013 and passes the significance test at the level of $5 \%$, which shows that compared with enterprises with no venture capital institutions, enterprises with venture capital institutions have a lower scale of excess goodwill. Hypothesis H1 has been verified again.

4.5. Remeasure Interpreted Variable. For excess goodwill above, we mainly use total assets to reduce the impact of size. Referring to Pan Hongbo et al.'s (2019) study [39], we use the net assets to reduce the impact of size and use the symbol GWover_Equity instead. Specifically, we divide the difference between the book value of goodwill of enterprise $i$ in year $t$ minus the average book value of goodwill of the industry in which the enterprise $i$ works by the final total assets of enterprise $i$. See Table 10 for the results after regression. In Table 10 , the coefficient of $\mathrm{VC}$ is -0.035 and passes the significance test at the level of $1 \%$, which shows that compared with enterprises with no venture capital institutions, and enterprises with venture capital institutions have a lower scale of excess goodwill. Hypothesis $\mathrm{H} 1$ has been verified again.

\section{Mechanism Analysis}

In this part, we will further explore the mechanism of the impact of venture capital institutions on the M\&A goodwill bubbles. In the research hypothesis, we think that the venture capital institutions may inhibit the M\&A goodwill bubbles through the following two aspects: (1) the venture capital institutions have the certification function, which can 
TABLE 8: DID regression results.

\begin{tabular}{lc}
\hline Variable & GWover \\
\hline Change & $0.039^{* * *}$ \\
& $(4.46)$ \\
LnSize & $0.192^{* * *}$ \\
& $(24.01)$ \\
SOE & $-0.059^{* * *}$ \\
& $(-4.52)$ \\
MB & $-0.012^{*}$ \\
& $(-1.94)$ \\
ROA & $-0.263^{* *}$ \\
& $(-2.34)$ \\
LEV & $-0.085^{* * *}$ \\
& $(-2.66)$ \\
Big4 & -0.006 \\
& $(-0.24)$ \\
Top1 & $-0.001^{* * *}$ \\
& $(-2.83)$ \\
Growth & $0.010^{*}$ \\
& $(1.65)$ \\
Turnover & $-0.037^{* * *}$ \\
Intercept & $(-2.94)$ \\
Year & $-4.136^{* * *}$ \\
Ind & $(-24.15)$ \\
N & Controlled \\
ADJ $R^{2}$ & Controlled \\
Syms & 1252 \\
& 0.66 \\
\hline
\end{tabular}

Symbols ${ }^{*},{ }^{* *}$, and ${ }^{* * *}$ indicate significance at the $10 \%, 5 \%$, and $1 \%$ levels, respectively. The value output in parentheses is the $t$ value.

reduce the information asymmetry, thus alleviating the problem of overvaluation of M\&A goodwill caused by valuation deviation. (2) Venture capital institutions have supervisory function, which can reduce agency conflicts, thus alleviating the problem of overestimation of M\&A goodwill caused by the motivation of interest delivery by the major shareholders and the motivation of opportunistic behavior by the management. The specific test methods are as follows.

5.1. Reduce Information Asymmetry. To verify that the certification and supervision role of venture capital institutions can reduce information asymmetry, we set up information scenarios according to the nature of enterprise property rights to conduct group testing. Compared with state-owned enterprises, non-state-owned enterprises have lower information transparency, worse management standardization, and less attention from government and market parties [36, 40], which lead to higher information asymmetry between them and external investors. Therefore, compared with state-owned enterprises, venture capital institutions can play a more certification role in non-state-owned enterprises and effectively suppress M\&A goodwill bubbles. The empirical regression results are shown in Table 11. In Table 11, we find that, in the non-state-owned enterprises, $\mathrm{VC}$ coefficient is -0.030 and passes the significance test at $1 \%$ level. However, in the state-owned enterprises, VC coefficient is negative, but it does not pass the significance test.
TABLE 9: Regression results of adding control variables.

\begin{tabular}{lc}
\hline Variable & GWover \\
\hline VC & $-0.013^{* *}$ \\
& $(-2.31)$ \\
LnSize & $0.175^{* * *}$ \\
& $(29.74)$ \\
SOE & $-0.045^{* * *}$ \\
& $(-4.07)$ \\
MB & $-0.022^{* * *}$ \\
& $(-4.44)$ \\
ROA & $-0.315^{* * *}$ \\
& $(-3.56)$ \\
LEV & $-0.046^{*}$ \\
& $(-1.88)$ \\
Big4 & -0.034 \\
& $(-1.53)$ \\
Top1 & $-0.001^{* * *}$ \\
Growth & $(-4.07)$ \\
Turnover & $0.017^{* * *}$ \\
Indpr & $(3.57)$ \\
& $-0.038^{* * *}$ \\
Dual & $(-4.09)$ \\
HHI & -0.012 \\
Market & $(-0.20)$ \\
Intercept & 0.001 \\
ADJ $R^{2}$ & $(0.10)$ \\
Symbors & -0.031 \\
& $(-0.95)$ \\
& 0.000 \\
& $(0.20)$ \\
& $-3.693^{* * *}$ \\
& $(-27.64)$ \\
& Controlled \\
& Controlled \\
& 2151 \\
& 0.64 \\
\hline
\end{tabular}

Symbols ${ }^{*},{ }^{* *}$, and ${ }^{* * *}$ indicate significance at the $10 \%, 5 \%$, and $1 \%$ levels, respectively. The value output in parentheses is the $t$ value.

This shows that venture capital institutions can suppress the goodwill bubbles more effectively when the degree of information asymmetry is higher.

5.2. Mitigating Agency Conflicts. Referring to the research of Xiao Zuoping and Chen Desheng (2006) [41], we take the turnover rate of total assets as the measure index of agency conflict between management and shareholders to conduct group testing. Specifically, if the company's total asset turnover rate in the current year is lower than the annual median, it will be taken as a high sample of agency conflict. On the contrary, it will be taken as a low group sample of agency conflict. Specific empirical regression results are shown in columns (1) and (2) of Table 12. Referring to the research of Luo Jinhui (2012) [42], we use the proportion of other receivables to total assets to measure agency conflict between large shareholders and minority shareholders to conduct group testing. Specifically, we divide the proportion of other receivables in total assets into quartiles, and the sample companies ranked in the lower quartile are the samples with high agency conflict. The sample companies 
TABLE 10: Replacement of explained variables.

\begin{tabular}{lc}
\hline Variable & GWover_Equity \\
\hline VC & $-0.035^{* * *}$ \\
& $(-4.12)$ \\
LnSize & $0.270^{* * *}$ \\
& $(30.55)$ \\
SOE & $-0.073^{* * *}$ \\
& $(-4.47)$ \\
MB & $-0.020^{* *}$ \\
& $(-2.56)$ \\
ROA & $-0.618^{* * *}$ \\
& $(-4.84)$ \\
LEV & $-0.467^{* * *}$ \\
& $(-10.71)$ \\
Big4 & -0.044 \\
Top1 & $(-1.14)$ \\
$(-3.65)$ & $-0.001^{* * *}$ \\
Growth & \\
(3.68) & $0.031^{* * *}$ \\
Turnover & \\
$(-3.21)$ & $-0.052^{* * *}$ \\
Intercept & \\
$(-28.59)$ & $-5.570^{* * *}$ \\
Year & \\
Ind & Controlled \\
N & Controlled \\
ADJ $R^{2}$ & 2162 \\
\hline Symo & 0.62 \\
\hline
\end{tabular}

Symbols ${ }^{*},{ }^{* *}$, and ${ }^{* * *}$ indicate significance at the $10 \%, 5 \%$, and $1 \%$ levels, respectively. The value output in parentheses is the $t$ value.

ranked in the top quartile are the low group samples of agency conflict. Specific empirical regression results are shown in columns (3) and (4) of Table 12. In Table 12, we find that, in the two groups with higher agency conflicts, coefficients of VC are -0.020 and -0.068 , respectively, and pass the significance test at least $5 \%$. In the two groups with lower agency conflicts, coefficients of $\mathrm{VC}$ are all negative but do not pass the significance test. This shows that venture capital institutions can inhibit the M\&A goodwill bubbles more effectively in enterprises with higher agency conflict.

\section{Further Analysis}

\subsection{Analysis of Venture Capital Participation}

6.1.1. Shareholding Ratio of Venture Capital Institutions. Column (1) of Table 13 shows the impact of the shareholding ratio of venture capital institutions on M\&A goodwill bubbles. In Table 13, VC_share represents the shareholding ratio of venture capital institutions, which is measured by the proportion of total equity held by the venture capital institution in the invested enterprise, and the remaining control variables are the same as equation (1). In Column (1) of Table 13, we find that the coefficient of VC_share is -0.001 and passes the significance test at the level of $10 \%$. It shows that the higher the shareholding ratio of venture capital institutions, the lower the scale of excess goodwill acquired by the invested enterprise. This may be because, on the one hand, for the target enterprise, the higher the shareholding ratio of the venture capital institutions in the acquirer, the more they can send the signal that the acquirer is of good quality to the target party. It can better reduce the information asymmetry between the acquirer and the target. On the other hand, for the acquirer, the higher the shareholding ratio of venture capital institutions in the acquirer, the more motivated they are to participate in the M\&A activities, and the greater their supervisory role in enterprises [31]. Therefore, it can better inhibit the motivation of interest delivery by the major shareholders and the motivation of opportunistic behavior by the management and finally effectively inhibit the goodwill bubbles.

6.1.2. Number of Venture Capital Institutions. Column (2) of Table 13 shows the impact of the number of venture capital institutions on M\&A goodwill bubbles. In Table 13, VC_js represents the number of venture capital institutions, which is measured by the total number of venture capital institutions invested in the same enterprise, and the remaining control variables are the same as equation (1). In column (2) of Table 13, we find that the coefficient of VC_js is -0.010 and passes the significance test at the level of $1 \%$. It shows that the more the number of venture capital institutions, the lower the scale of excess goodwill acquired by the invested enterprise. This may be because the more venture capital institutions invest in the same enterprise, the wider the social network they form. It can help the enterprise better assess the value of the target assets. At the same time, supervision by many venture capital institutions can make up for the defect that a single venture capital institution cannot continue to supervise enterprises under the condition of own limited energy. The better play of certification and supervision can better inhibit M\&A goodwill bubbles.

\subsection{Analysis of Internal and External Governance Environment}

6.2.1. Analysis of Internal Governance Environment. Specifically, if the company's internal control quality in the current year is higher than the annual and industry median, it will be taken as a sample with high internal control quality. On the contrary, it will be taken as a sample with low internal control quality. The empirical regression results are shown in Table 14. In Table 14, we find that the coefficient of VC is -0.016 in the group with lower internal control level and passes the significance test at $10 \%$ level. However, in the groups with higher internal control level, the coefficient of VC does not pass the significance test. This shows that venture capital institutions can better play the role of certification and supervision in enterprises with lower internal control level, so as to effectively inhibit the M\&A goodwill bubbles. Therefore, when the internal supervision environment is relatively weak, the enterprise can make up for the deficiency of its own supervision with the help of private supervision conducted by venture capital institutions in the face of goodwill bubbles. 
TABLE 11: Regression results of reducing information asymmetry.

\begin{tabular}{|c|c|c|}
\hline Variable & $\begin{array}{c}\text { GWover } \\
\text { State-owned enterprise }\end{array}$ & $\begin{array}{c}\text { GWover } \\
\text { Non-state-owned enterprise }\end{array}$ \\
\hline VC & $\begin{array}{l}-0.013 \\
(-0.41)\end{array}$ & $\begin{array}{c}-0.030^{* * *} \\
(-3.43)\end{array}$ \\
\hline LnSize & $\begin{array}{l}0.234^{* * *} \\
(8.95)\end{array}$ & $\begin{array}{c}0.282^{* * *} \\
(29.74)\end{array}$ \\
\hline $\mathrm{MB}$ & $\begin{array}{l}-0.003 \\
(-0.20)\end{array}$ & $\begin{array}{c}-0.018^{* *} \\
(-2.17)\end{array}$ \\
\hline ROA & $\begin{array}{l}-0.319 \\
(-0.90)\end{array}$ & $\begin{array}{c}-0.687^{* * *} \\
(-5.15)\end{array}$ \\
\hline LEV & $\begin{array}{c}-0.550^{* * *} \\
(-4.03)\end{array}$ & $\begin{array}{c}-0.458^{* * *} \\
(-10.12)\end{array}$ \\
\hline Big4 & $\begin{array}{l}0.032 \\
(0.45)\end{array}$ & $\begin{array}{l}-0.065 \\
(-1.48)\end{array}$ \\
\hline Top1 & $\begin{array}{l}0.001 \\
(0.70)\end{array}$ & $\begin{array}{c}-0.001^{* * *} \\
(-3.37)\end{array}$ \\
\hline Growth & $\begin{array}{l}-0.004 \\
(-0.40)\end{array}$ & $\begin{array}{c}0.035^{* * *} \\
(3.82)\end{array}$ \\
\hline Turnover & $\begin{array}{c}0.125^{* * *} \\
(3.11)\end{array}$ & $\begin{array}{c}-0.064^{* * *} \\
(-3.87)\end{array}$ \\
\hline Intercept & $\begin{array}{c}-5.590^{* * *} \\
(-9.08)\end{array}$ & $\begin{array}{c}-5.834^{* * *} \\
(-27.74)\end{array}$ \\
\hline Year & Controlled & Controlled \\
\hline Ind & Controlled & Controlled \\
\hline $\mathrm{N}$ & 186 & 1976 \\
\hline $\mathrm{ADJ} R^{2}$ & 0.73 & 0.63 \\
\hline
\end{tabular}

Symbols ${ }^{*},{ }^{* *}$, and ${ }^{* * *}$ indicate significance at the $10 \%, 5 \%$, and $1 \%$ levels, respectively; the value output in parentheses is the $t$ value.

TABLE 12: Regression results of mitigating agency conflicts.

\begin{tabular}{|c|c|c|c|c|}
\hline Variable & $\begin{array}{c}\text { (1) GWover } \\
\text { Proxy conflict higher group }\end{array}$ & $\begin{array}{c}\text { (2) GWover } \\
\text { Proxy conflict lower group }\end{array}$ & $\begin{array}{c}\text { (3) GWover } \\
\text { Proxy conflict higher group }\end{array}$ & $\begin{array}{c}\text { (4) GWover } \\
\text { Proxy conflict lower group }\end{array}$ \\
\hline VC & $\begin{array}{c}-0.020^{* *} \\
(-2.26)\end{array}$ & $\begin{array}{l}-0.004 \\
(-0.55)\end{array}$ & $\begin{array}{c}-0.068^{* * *} \\
(-2.68)\end{array}$ & $\begin{array}{l}-0.004 \\
(-0.47)\end{array}$ \\
\hline LnSize & $\begin{array}{c}0.191^{* * *} \\
(22.67)\end{array}$ & $\begin{array}{c}0.153^{* * *} \\
(19.19)\end{array}$ & $\begin{array}{c}0.112^{* * *} \\
(7.25)\end{array}$ & $\begin{array}{c}0.171^{* * *} \\
(15.54)\end{array}$ \\
\hline SOE & $\begin{array}{c}-0.049^{* * *} \\
(-3.80)\end{array}$ & $\begin{array}{c}-0.042^{* *} \\
(-2.09)\end{array}$ & $\begin{array}{l}0.006 \\
(0.18)\end{array}$ & $\begin{array}{l}-0.032 \\
(-1.57)\end{array}$ \\
\hline MB & $\begin{array}{c}-0.019^{* * *} \\
(-2.70)\end{array}$ & $\begin{array}{c}-0.021^{* * *} \\
(-3.11)\end{array}$ & $\begin{array}{c}-0.040^{* * *} \\
(-3.08)\end{array}$ & $\begin{array}{c}-0.022^{* * *} \\
(-2.71)\end{array}$ \\
\hline ROA & $\begin{array}{c}-0.540^{* * *} \\
(-4.33)\end{array}$ & $\begin{array}{l}-0.104 \\
(-0.87)\end{array}$ & $\begin{array}{l}0.156 \\
(0.91)\end{array}$ & $\begin{array}{l}-0.129 \\
(-0.93)\end{array}$ \\
\hline LEV & $\begin{array}{c}-0.080^{* *} \\
(-2.43)\end{array}$ & $\begin{array}{l}0.032 \\
(0.94)\end{array}$ & $\begin{array}{l}0.012 \\
(0.17)\end{array}$ & $\begin{array}{l}0.020 \\
(0.52)\end{array}$ \\
\hline Big4 & $\begin{array}{l}-0.022 \\
(-0.89)\end{array}$ & $\begin{array}{l}-0.004 \\
(-0.11)\end{array}$ & $\begin{array}{l}0.079 \\
(0.96)\end{array}$ & $\begin{array}{c}-0.063^{*} \\
(-1.90)\end{array}$ \\
\hline Top1 & $\begin{array}{c}-0.001^{* * *} \\
(-3.66)\end{array}$ & $\begin{array}{l}-0.000 \\
(-1.50)\end{array}$ & $\begin{array}{l}-0.001 \\
(-1.45)\end{array}$ & $\begin{array}{c}-0.001^{* * *} \\
(-3.29)\end{array}$ \\
\hline Growth & $\begin{array}{c}0.019^{* * *} \\
(3.25)\end{array}$ & $\begin{array}{c}0.022^{* * *} \\
(3.04)\end{array}$ & $\begin{array}{l}-0.001 \\
(-0.39)\end{array}$ & $\begin{array}{c}0.001^{* * *} \\
(2.76)\end{array}$ \\
\hline Intercept & $\begin{array}{c}-4.004^{* * *} \\
(-21.54)\end{array}$ & $\begin{array}{c}-3.371^{* * *} \\
(-18.28)\end{array}$ & $\begin{array}{c}-0.056^{* * *} \\
(-3.15)\end{array}$ & $\begin{array}{c}-0.035^{* *} \\
(-2.16)\end{array}$ \\
\hline Year & Controlled & Controlled & Controlled & Controlled \\
\hline Ind & Controlled & Controlled & Controlled & Controlled \\
\hline $\mathrm{N}$ & 1080 & 1082 & 147 & 1051 \\
\hline $\mathrm{ADJ} R^{2}$ & 0.62 & 0.68 & 0.52 & 0.61 \\
\hline
\end{tabular}

Symbols ${ }^{*},{ }^{* *}$, and ${ }^{* * *}$ indicate significance at the $10 \%, 5 \%$, and $1 \%$ levels, respectively. The value output in parentheses is the $t$ value. 
TABLE 13: Regression results of venture capital participation.

\begin{tabular}{|c|c|c|}
\hline Variable & $\begin{array}{c}(1) \\
\text { GWover }\end{array}$ & $\begin{array}{c}(2) \\
\text { GWover }\end{array}$ \\
\hline VC_share & $\begin{array}{c}-0.001^{*} \\
(-1.66)\end{array}$ & \\
\hline VC_js & & $\begin{array}{c}-0.010^{* * *} \\
(-2.95)\end{array}$ \\
\hline LnSize & $\begin{array}{c}0.201^{* * *} \\
(20.13)\end{array}$ & $\begin{array}{c}0.188^{* * *} \\
(19.20)\end{array}$ \\
\hline SOE & $\begin{array}{c}-0.079^{* * *} \\
(-4.87)\end{array}$ & $\begin{array}{c}-0.075^{* * *} \\
(-4.71)\end{array}$ \\
\hline MB & $\begin{array}{l}-0.011 \\
(-1.45)\end{array}$ & $\begin{array}{c}-0.016^{* *} \\
(-2.11)\end{array}$ \\
\hline ROA & $\begin{array}{l}-0.199 \\
(-1.52)\end{array}$ & $\begin{array}{l}-0.102 \\
(-0.81)\end{array}$ \\
\hline LEV & $\begin{array}{l}-0.046 \\
(-1.17)\end{array}$ & $\begin{array}{l}-0.023 \\
(-0.64)\end{array}$ \\
\hline Big4 & $\begin{array}{l}-0.007 \\
(-0.24)\end{array}$ & $\begin{array}{l}0.001 \\
(0.04)\end{array}$ \\
\hline Top1 & $\begin{array}{c}-0.001^{* * *} \\
(-3.04)\end{array}$ & $\begin{array}{c}-0.001^{* *} \\
(-2.49)\end{array}$ \\
\hline Growth & $\begin{array}{c}0.013^{*} \\
(1.68)\end{array}$ & $\begin{array}{c}0.011 \\
(1.50)\end{array}$ \\
\hline Turnover & $\begin{array}{c}-0.022^{*} \\
(-1.79)\end{array}$ & $\begin{array}{c}-0.037^{* *} \\
(-2.58)\end{array}$ \\
\hline Intercept & $\begin{array}{c}-4.283^{* * *} \\
(-20.28)\end{array}$ & $\begin{array}{c}-4.002^{* * *} \\
(-19.06)\end{array}$ \\
\hline Year & Controlled & Controlled \\
\hline Ind & Controlled & Controlled \\
\hline $\mathrm{N}$ & 987 & 1018 \\
\hline ADJ $R^{2}$ & 0.69 & 0.68 \\
\hline
\end{tabular}

Symbols ${ }^{*},{ }^{* *}$, and ${ }^{* * *}$ indicate significance at the $10 \%, 5 \%$, and $1 \%$ levels, respectively. The value output in parentheses is the $t$ value.

TABLE 14: Regression results of internal control.

\begin{tabular}{|c|c|c|}
\hline Variable & $\begin{array}{c}\text { GWover } \\
\text { Internal control high group }\end{array}$ & $\begin{array}{c}\text { GWover } \\
\text { Internal control low group }\end{array}$ \\
\hline $\mathrm{VC}$ & $\begin{array}{l}-0.010 \\
(-1.23)\end{array}$ & $\begin{array}{c}-0.016^{*} \\
(-1.90)\end{array}$ \\
\hline LnSize & $\begin{array}{c}0.182^{* * *} \\
(21.85)\end{array}$ & $\begin{array}{c}0.171^{* * *} \\
(19.52)\end{array}$ \\
\hline SOE & $\begin{array}{c}-0.061^{* * *} \\
(-3.56)\end{array}$ & $\begin{array}{c}-0.040^{* *} \\
(-2.94)\end{array}$ \\
\hline MB & $\begin{array}{c}-0.016^{* *} \\
(-2.38)\end{array}$ & $\begin{array}{c}-0.027^{* * *} \\
(4.13)\end{array}$ \\
\hline ROA & $\begin{array}{c}-0.406^{* * *} \\
(-3.06)\end{array}$ & $\begin{array}{l}-0.039 \\
(-1.26)\end{array}$ \\
\hline LEV & $\begin{array}{r}-0.054^{*} \\
(-1.49)\end{array}$ & $\begin{array}{c}-0.005 \\
(0.20)\end{array}$ \\
\hline Big4 & $\begin{array}{l}-0.011 \\
(-0.34)\end{array}$ & $\begin{array}{c}-0.002^{*} \\
(-0.74)\end{array}$ \\
\hline Top1 & $\begin{array}{l}-0.000 \\
(-1.37)\end{array}$ & $\begin{array}{c}-0.000^{* * * *} \\
(-4.21)\end{array}$ \\
\hline Growth & $\begin{array}{c}0.024^{* *} \\
(2.08)\end{array}$ & $\begin{array}{r}-0.005^{*} \\
(1.67)\end{array}$ \\
\hline Turnover & $\begin{array}{c}-0.055^{* * *} \\
(-4.20)\end{array}$ & $\begin{array}{c}0.001 \\
(-1.44)\end{array}$ \\
\hline Intercept & $\begin{array}{c}-3.986^{* * *} \\
(-21.03)\end{array}$ & $\begin{array}{c}-3.634^{* * *} \\
(-18.59)\end{array}$ \\
\hline Year & Controlled & Controlled \\
\hline Ind & Controlled & Controlled \\
\hline $\mathrm{N}$ & 977 & 981 \\
\hline ADJ $R^{2}$ & 0.66 & 0.65 \\
\hline
\end{tabular}

Symbols ${ }^{*},{ }^{* *}$, and ${ }^{* * *}$ indicate significance at the $10 \%, 5 \%$, and $1 \%$ levels, respectively. The value output in parentheses is the $t$ value. 
TABLE 15: Regression results of external control.

\begin{tabular}{|c|c|c|}
\hline Variable & $\begin{array}{c}\text { GWover } \\
\text { Marketization level high group }\end{array}$ & $\begin{array}{c}\text { GWover } \\
\text { Marketization level Low group }\end{array}$ \\
\hline VC & $\begin{array}{l}-0.011 \\
(-1.60)\end{array}$ & $\begin{array}{c}-0.019^{* *} \\
(-2.56)\end{array}$ \\
\hline LnSize & $\begin{array}{c}0.169^{* * *} \\
(25.26)\end{array}$ & $\begin{array}{c}0.184^{* * *} \\
(25.77)\end{array}$ \\
\hline SOE & $\begin{array}{c}-0.038^{* *} \\
(-2.36)\end{array}$ & $\begin{array}{c}-0.052^{* * *} \\
(-4.44)\end{array}$ \\
\hline MB & $\begin{array}{c}-0.013^{* *} \\
(-2.15)\end{array}$ & $\begin{array}{c}-0.022^{* * *} \\
(-3.34)\end{array}$ \\
\hline ROA & $\begin{array}{c}-0.303^{* * *} \\
(-2.66)\end{array}$ & $\begin{array}{c}-0.592^{* * *} \\
(-4.88)\end{array}$ \\
\hline LEV & $\begin{array}{l}0.038 \\
(1.20)\end{array}$ & $\begin{array}{c}-0.154^{* * *} \\
(-4.76)\end{array}$ \\
\hline Big4 & $\begin{array}{c}-0.059^{* * *} \\
(-2.68)\end{array}$ & $\begin{array}{l}0.006 \\
(0.15)\end{array}$ \\
\hline Top1 & $\begin{array}{c}-0.001^{* * *} \\
(-3.04)\end{array}$ & $\begin{array}{l}-0.000 \\
(-1.47)\end{array}$ \\
\hline Growth & $\begin{array}{c}0.031^{* * *} \\
(2.98)\end{array}$ & $\begin{array}{c}0.047^{* * *} \\
(5.85)\end{array}$ \\
\hline Turnover & $\begin{array}{c}-0.050^{* * *} \\
(-3.91)\end{array}$ & $\begin{array}{c}-0.030^{* *} \\
(-2.40)\end{array}$ \\
\hline Intercept & $\begin{array}{c}-3.505^{* * *} \\
(-21.53)\end{array}$ & $\begin{array}{c}-3.879^{* * *} \\
(-24.54)\end{array}$ \\
\hline Year & Controlled & Controlled \\
\hline Ind & Controlled & Controlled \\
\hline $\mathrm{N}$ & 963 & 1188 \\
\hline $\mathrm{ADJ} R^{2}$ & 0.71 & 0.67 \\
\hline
\end{tabular}

Symbols ${ }^{*},{ }^{* *}$, and ${ }^{* * *}$ indicate significance at the $10 \%, 5 \%$, and $1 \%$ levels, respectively. The value output in parentheses is the $t$ value.

6.2.2. Analysis of External Governance Environment. We used the marketization index in China's Provincial Marketization Index Report (2018) compiled by Wang Xiaolu to measure the marketization level for grouping test. As the data listed in the report only come to 2016, we use the trend analysis method (three-year rolling period) to calculate the marketization index from 2017 to 2018. Specifically, if the marketization level of the company in the current year is higher than the median of the annual median, it will be taken as the sample with high marketization level; otherwise, it will be taken as the sample with low marketization level. The empirical regression results are shown in Table 15 . In Table 15 , we find that the coefficient of VC is -0.019 in the group with low marketization level and passes the significance test at 5\% level. However, in the groups with high marketization level, the coefficient of VC does not pass the significance test. This shows that venture capital institutions can better play the role of certification and supervision in enterprises with low marketization level so as to effectively inhibit the M\&A goodwill bubbles. Therefore, when the external supervision environment is relatively weak, the enterprise can make up for the deficiency of its own supervision with the help of private supervision conducted by venture capital institutions in the face of goodwill bubbles.

\section{Conclusions}

The problem of goodwill bubbles is an important issue in the current capital market. It is of great significance to explore the influencing factors of goodwill bubbles for effectively inhibiting goodwill bubbles and preventing and resolving financial risks. Different from previous studies, this paper examines the impact of venture capital institutions on M\&A goodwill bubbles from the perspective of venture capital. The results of multiple linear regression shows that compared with nonventure capital shareholding companies, the scale of M\&A excess goodwill of venture capital shareholding companies is lower. That is, venture capital institutions can effectively inhibit M\&A goodwill bubbles. After using Heckman two-stage regression, propensity score matching (PSM), double difference method (DID), adding control variables, and replacing the interpreted variables for robustness test, the above conclusions are still valid. Venture capital institutions are more likely to reduce excess goodwill in non-state-owned enterprises with higher information asymmetry and enterprises with more serious agency conflicts between management and shareholders and major shareholders' encroachment on the interests of minority shareholders. That is, venture capital institutions can effectively inhibit the M\&A goodwill bubbles by reducing information asymmetry and easing agency conflict between managers and shareholders and between major shareholders and minority shareholders.

From the perspective of the participation of venture capital institutions, the higher the shareholding of venture capital institutions and the greater the number of venture capital institutions investing in the same company, the more they can inhibit M\&A goodwill bubbles. From the 
perspective of internal governance environment, venture capital institutions are more able to inhibit M\&A goodwill bubbles in enterprises with lower internal control quality. This shows when the internal supervision environment is relatively weaker, the enterprise can make up for the deficiency of its own supervision with the help of private supervision conducted by venture capital institutions in the face of goodwill bubbles. This can provide empirical evidence for the listed companies whether and how to introduce venture capital institutions. For listed companies, especially those whose internal supervision environment is relatively weak, when making M\&A decisions, they should strengthen the benign interaction between themselves and venture capital institutions and actively create favorable conditions for venture capital institutions to participate in M\&A decisions. If possible, they should consider increasing the shareholding ratio of venture capital institutions or introducing several venture capital institutions at the same time so as to give full play to the supervision function of the certification and supervision of venture capital institutions to inhibit M\&A goodwill bubbles.

From the perspective of external governance environment, venture capital institutions are more able to inhibit M\&A goodwill bubbles in enterprises with poor marketization level. Private monitoring through venture capital institutions substitutes for public enforcement in the context of goodwill bubbles when a country's enforcement regime is relatively weak. Therefore, it can provide empirical evidence for the government and relevant regulatory departments to optimize M\&A regulatory policies. With the current goodwill bubbles accumulation and the high incidence of goodwill impairment, it is far from enough to rely solely on government supervision. Government regulatory departments should make full use of the active role played by external supervision institutions such as venture capital institutions in the process of M\&A to guide the healthy development of venture capital industry and jointly maintain the smooth development of capital market with venture capital institutions.

\section{Data Availability}

The statistical data used to support the findings of this study were supplied by CVSOURCE database and WIND database under license and so cannot be made freely available. Requests for access to these data should be made to Juntao Lan, 201701090024@stu.zuel.edu.cn.

\section{Conflicts of Interest}

The authors declare that they have no conflicts of interest.

\section{References}

[1] L. Gao and S. Yuan, "Analysis of the goodwill and devaluation of listed companies in M\&A," Securities Market Herald, vol. 12, pp. 60-66, 2017.

[2] H. Han, Q. Tang, and W. Li, "M\&A goodwill impairment, information asymmetry and stock price collapse risk," $\mathrm{Se}$ curities Market Herald, vol. 320, no. 3, pp. 59-70, 2019.
[3] Y. Lin, W. Lu, and H. Chen, "Goodwill and goodwill impairment: deep analysis based on the status quo of listed companies," Shanghai Securities News, vol. 4, no. 15, 2017.

[4] Y. Lu and X. Qu, "Earnings management motivations of goodwill impairment-— the empirical evidence from Chinese a-share market," Journal of Shanxi University of Finance and Economics, vol. 38, no. 7, pp. 87-99, 2016.

[5] Y. Zang, "Discretionary behaviour with respect to the adoption of SFAS No. 142 and the behavior of security prices," Review of Accounting and Finance, vol. 7, pp. 38-68, 2008.

[6] B. Masters-Stout, M. L. Costigan, and L. M. Lovata, "Goodwill impairments and chief executive officer tenure," Critical Perspectives on Accounting, vol. 19, pp. 70-83, 2008.

[7] H. Wang, B. Wang, and Z. Zhou, "Returnee audit committee and goodwill impairment provision," Auditing and Economic Research, vol. 36, pp. 58-67, 2021.

[8] X. Zhang, Q. Chen, and D. Yang, "Internal control and curb of abnormal goodwill: empirical evidence from Chinese listed firm," Journal of Xiamen University, vol. 247, pp. 55-65, 2018.

[9] G. Xu, "Can corporate social responsibility inhibit goodwill bubbles?" Auditing and Economic Research, vol. 35, pp. 90-99, 2020.

[10] J. Francis, J. Hanna, and L. Vincent, "Causes and effects of discretionary asset write-offs," Journal of Accounting Research, vol. 34, pp. 117-134, 1996.

[11] Li. Lu and H. Yao, "Can shared auditors inhibit M\&A goodwill bubbles? The evidence from Chinese listed companies," Auditing and Economic Research, vol. 5, pp. 32-42, 2019.

[12] M. Glaum, W. R. Landsman, and S. Wyrwa, "Goodwill impairment: the effects of public enforcement and monitoring by institutional investors," The Accounting Review, vol. 6, pp. 149-180, 2018.

[13] C. Wu, S. Wu, J. Cheng, and L. Wang, "The role of venture capital in the investment and financing behavior of listed companies: evidence from china," Economic Research, vol. 47, pp. 105-119, 2012.

[14] Li Yao and H. Song, "On the effects of mergers and acquisitions performance of venture capital backed ChiNext companies," Accounting Research, vol. 7, pp. 60-66, 2017.

[15] X. Du, Y. Du, and Z. Zhou, "Study on the connotation and recognition of goodwill," Accounting Research, vol. 1, pp. 11-18, 2011.

[16] C. Fu, J. Wang, and D. Fu, "Has goodwill been overstated with its merging? empirical evidence from a Share market listed companies in China," China's economic issues, vol. 6, pp. 109-123, 2016.

[17] H. Zheng, Z. Liu, and W. Feng, "Can merger and acquisition goodwill promote company performance?--empirical evidence from Chinese a-shares listed companies," Accounting Research, vol. 3, pp. 11-17, 2014.

[18] Z. Guo, Y. Wang, and W. Lingyun, "Merger and acquisition goodwill and corporate technological innovation," Scientific Research Management, vol. 42, pp. 77-87, 2021.

[19] X. Qu, Yu Lu, and R. Zhang, "Value relevance of goodwill impairments: empirical evidence from Chinese a-share market," Economic and Management Research, vol. 3, pp. 122-132, 2017.

[20] C. Zheng and L. Xiao, "Merger goodwill and audit service pricing," Audit Research, vol. 206, pp. 113-120, 2018.

[21] N. M. Abughazaleh, O. M. Al-Hares, and C. Roberts, "Accounting discretion in goodwill impairments: UK evidence," Journal of International Financial Management \& Accounting, vol. 22, pp. 165-204, 2011. 
[22] R. Li, L. Lu, T. Cui, and W. Gu, "Assessing the attraction of cities on venture capital from a scaling law perspective," IEEE Access, vol. 9, pp. 48052-48063, 2021.

[23] S. Li, J. Yang, and J. Zhong, "Do venture capitals have the consulting function? evidence from research on the function of venture capitals in Inter-regional M\&A," Management world, vol. 35, pp. 164-180, 2019.

[24] J. Dong and J. Yu, "Venture capital's regional experience and firm's cross-regional M\&As," Economic management, vol. 43, pp. $88-107,2021$

[25] G. Nguyen and L. Vu, "Does venture capital syndication affect M\&A?" Journal of Corporate Finance, vol. 67, Article ID 101851, 2021.

[26] K. Ramanna, "The implications of unverifiable fair-value accounting: evidence from the political economy of goodwill accounting," Journal of Accounting and Economics, vol. 45, pp. 253-281, 2008.

[27] K. K. Li and R. G. Sloan, "Has goodwill accounting gone bad?" Review of Accounting Studies, vol. 22, pp. 964-1003, 2017.

[28] D. Li, J. Ye, S. Lu, and S. Zeng, "Management overconfidence, nature of property rights and goodwill from M\&A activities," Accounting research, vol. 10, pp. 50-57, 2018.

[29] W. L. Megginson and K. A. Weiss, "Venture capitalist certification in initial public offerings," The Journal of Finance, vol. 46, pp. 879-903, 1991.

[30] T. J. Chemmanur and E. Loutskina, "The Role of venture capital backing in initial public offerings: certification, screening, or market power?" SSRN Electronic Journal, 2006.

[31] T. Hellmann and M. Puri, "Venture capital and the professionalization of start-up firms: empirical evidence," The Journal of Finance, vol. 57, pp. 169-197, 2002.

[32] S. N. Kaplan and P. Stromberg, "Financial contracting theory meets the real world: an empirical analysis of venture capital contracts," The Review of Economic Studies, vol. 70, pp. 281-315, 2003.

[33] M. Baker and P. Gompers, "The determinants of board structure at the initial public offering," The Journal of Law and Economics, vol. 46, pp. 569-598, 2003.

[34] R. Yuan, W. Wen, and Li. Wang, "Venture capital and governance of IPO companies' board: an empirical analysis based on propensity score matching method," China Soft Science, vol. 24, pp. 118-128, 2014.

[35] J. Dong, J. Wang, H. Zhai, and L. Wang, "Value-added service or supervisory control? management patterns of venture capital institutes to entrepreneurial firms: views from industrial specialty and uncertainty," Management World, vol. 6, pp. 82-103, 2017.

[36] L. Hu and Z. Zhou, "Can venture capital shareholding relieve corporate follow-on financing constraints? empirical evidence from Chinese listed companies," Economics and Management, vol. 40, pp. 93-111, 2018.

[37] M. J. Slaughter, "Trade liberalization and per capita income convergence: a difference-in-differences analysis," Journal of International Economics, vol. 55, pp. 203-228, 2011.

[38] M. Bertrand and S. Mullainathan, "Enjoying the quiet life? Corporate governance and managerial preferences," Journal of Political Economy, vol. 111, pp. 1043-1075, 2003.

[39] H. Pan, P. Rao, and Z. Zhang, "M. \& A arbitrage view: empirical evidence from insider reduction," Economics and Management, vol. 3, pp. 107-123, 2019.

[40] Z. Xu, J. Huang, and Y. Guo, "Government subsidies, enterprises' property and over-investment-—an empirical research based on the data of China's a-share listed companies," Journal of Beijing University of Industry and Commerce (Social Science Edition), vol. 1, pp. 73-84, 2017.

[41] Z. Xiao and D. Chen, "The impact of corporate governance structure on agency costs - empirical Evidence from Chinese listed companies," Finance and Trade Economics, vol. 12, pp. 29-35, 2006.

[42] J. Luo, "The role of corporate governance reported by the media - from the perspective of dual agency costs," Financial Research, vol. 10, pp. 153-166, 2012. 